DOI: https://doi.org/10.24127/ajpm.v10i3.3801

\title{
KONFLIK INTRAPERSONAL SISWA DALAM BELAJAR MATEMATIKA SECARA DARING SYNCHRONOUS
}

\author{
Kiki Henra $^{1 *}$, Ika Nirmala Masliah ${ }^{2}$ \\ ${ }^{1,2}$ Universitas Puangrimaggalatung, Wajo, Indonesia \\ *Corresponding author. Sengkang, 90911, Wajo, Indonesia. \\ E-mail: $\quad$ henrakiki@gmail.com ${ }^{1 *}$ \\ ikanirmala.hend@gmail.com $^{2)}$
}

Received 13 June 2021; Received in revised form 13 September 2021; Accepted 27 September 2021

\begin{abstract}
Abstrak
Tujuan penelitian ini adalah untuk memberikan gambaran tentang konflik intrapersonal siswa yang terjadi saat belajar matematika secara daring synchronous. Penelitian ini menggunakan metode deskriptif dengan pendekatan kualitatif. Pelaksanaan penelitian ini di SMA Negeri 3 Wajo pada siswa kelas XI sebanyak 44 yang melaksanakan pembelajaran secara daring menggunakan Zoom. Proses pengumpulan data dilakukan menggunakan instrumen kuesioner, lembar observasi, dan wawancara. Menggunakan teknik analisis data model Miles dan Huberman pada penelitian ini menunjukkan hasil bahwa konflik intrapersonal masih tetap terjadi pada siswa ketika belajar matematika secara daring synchronous, berdasarkan hasil wawancara siswa mengalami Approach-approach, Avoidance-avoidance, dan Approach-avoidance mereka mengalami kondisi tegang, cemas, takut, dan kebingungan ketika diberikan soal atau pertanyaan. Penyebab utama dari konflik intrapersonal yang dialami oleh siswa tersebut dikarenakan pemikiran bahwa belajar matematika itu menakutkan, ada 77,3\% siswa merasa takut ketika disuruh menjawab soal matematika oleh guru, terlebih materi pembelajaran yang dilakukan secara daring yang tidak mampu dipahami dengan baik karena kendala teknis jaringan. Berdasarkan hasil kuesioner, terdapat 72,2\% siswa mengalami kendala jaringan saat belajar matematika secara daring synchronous.
\end{abstract}

Kata kunci: Konflik intrapersonal; pembelajaran matematika; synchronous.

\begin{abstract}
The purpose of this study is to provide an overview of the intrapersonal conflicts students that occurred while learning mathematics online synchronously. This research uses descriptive methods with a qualitative approach. The implementation of this research at SMA Negeri 3 Wajo in grade XI students who conducted online learning using Zoom. The data collection process is conducted using questionnaire instruments, observation sheets, and interviews. Using data analysis techniques from the Miles and Huberman models in this study, the results show that intrapersonal conflicts still occur in students when learning mathematics online synchronously, based on the results of interviews, students experience Approach-approach, Avoidance-avoidance, and Approach-avoidance they experience tense conditions, anxiety, fear, and confusion when given a question or question.. The main cause of intrapersonal conflict experienced by the student is because of the thought that learning mathematics is scary. $77.3 \%$ of students feel afraid when told to answer math problems by teachers, especially learning materials conducted online that are not able to be understood properly because of network technical constraints. Based on the results of the questionnaire, $72.2 \%$ of students experienced network problems while learning math online synchronously.
\end{abstract}

Keywords: Intrapersonal conflict; mathematics learning; synchronous.

This is an open access article under the Creative Commons Attribution 4.0 International License 
DOI: https://doi.org/10.24127/ajpm.v10i3.3801

\section{PENDAHULUAN}

Semenjak pandemi Covid-19 melanda dunia khususnya Indonesia dari tahun 2020 segala aktivitas menjadi terganggu dan memaksa para pelaku pendidikan melakukan suatu perubahan dalam menyesuaikan keadaan untuk menekan penyebaran virus tersebut. Terkhusus di bidang pendidikan juga terdampak sehingga proses pembelajaran harus dirotasi dari tatap muka menjadi pembelajaran dalam jaringan. Pembelajaran daring berpotensi menjadi keuntungan atau kerugian dalam pembelajaran matematika yang berkarakter logis, sistematis dan simbolis (Hamidy, 2021). Hal ini nampak berbeda pada penelitian Al-Halik, \& Aini Z. (2020) menunjukkan secara umum keaktifan dan hasil belajar siswa dalam pembelajaran online berada pada kategori tinggi. Namun ada perbedaan dengan temuan yang dikemukakan oleh Lo \& Hew bahwa hasil pembelajaran matematika siswa menurun ketika pembelajaran daring (Hamidy, 2021).

Menurut Narayana (2016), dalam penelitiannya mengatakan bahwa pembelajaran daring model synchronous lebih baik sebanyak 2,2 point dari pada model asynchronous.

Pembelajaran synchronous yang dilakukan dengan terstruktur dan baik dapat membantu siswa merasakan hubungan yang lebih kuat dengan rekan dan guru mereka, serta dapat tetap terlibat dengan kegiatan pembelajaran. Untuk menyediakan ruang belajar yang bermakna dalam lingkungan belajar dengan pendekatan synchronous, guru tetap harus menyeimbangkan ketegangan dengan merangkul secara fleksibel yang diberikan di ruang online kepada siswa dan merancang struktur yang disengaja yang akan membantu mereka memanfaatkan ruang fleksibel tersebut (Yamagata-Lynch, 2014).
Ketika kebijakan pembelajaran daring ditetapkan, hampir seluruh pihak yang terlibat yaitu pendidik, peserta pendidik dan orang tua mengalami kegagapan dalam pemanfaatan media $e$ learning. Karena memang sebagian besar sekolah di Indonesia selama ini fokus pada pembelajaran tatap muka. Belum banyak lembaga pendidikan yang mengembangkan pembelajaran jarak jauh (PJJ) sehingga sekolah belum memiliki learning management system $\mathrm{s}$ (LMS) yang dikembangkan dan diterapkan dalam pembelajara. Kajian tentang pembelajaran online dan kepuasan hasil pembelajaran menjelaskan terdapat ketidakpuasan terhadap hasil (Fahmi, 2020).

Khususnya pada pembelajaran matematika, pada kenyataannya pelaksanaan pembelajaran matematika pada masa pandemi Covid-19 masih kurang efektif. Siswa kesulitan menerima pembelajaran matematika saat tatap muka, terlebih lagi saat menghadapi pembelajaran daring (Wulan, Rosita, \& Nopriana, 2021). Siswa masih kesultian dalam memahami materi matematika dan belum mampu sepenuhnya menikmati proses pembelajaran. Hal ini juga diperkuat hasil penelitian Wiryanto (2020) menyatakan bahwa pembelajaran secara online yang dilakukan guru dan murid tidak bisa memberikan feedback dengan cepat, pemahaman materi kurang mendalam, dan pelajar tidak memiliki motivasi tinggi dan cenderung gagal.

Dalam proses belajar mengajar matematika, khususnya yang dilaksanakan pada lembaga-lembaga pendidikan formal terdapat beberapa komponen yang biasa mempengaruhi, salah satunya adalah keadaan emosional atau psikologis siswa itu sendiri. Emosi berpengaruh besar pada kualitas dan kuantitas belajar positif dapat 
mempercepat proses belajar dan mencapai hasil belajar yang lebih baik, sebaliknya emosi yang negatif dapat memperlambat belajar atau bahkan menghentikannya sama sekali (Meiner, dikutip dalam Henra, 2020)

Salah satu penyebab siswa sulit menerima pembelajaran yaitu psikologi siswa rendah terhadap pembelajaran matematika, jika kondisi psikologi siswa rendah maka siswa sulit menerima materi dari guru yang juga berpengaruh terhadap hasil belajar, motivasi belajar serta prestasi belajar matematika (Siregar, 2018). Maka dari itu psikologi sangat penting dalam pembelajaran matematika. Setiap guru wajib mempelajari psikologi pendidikan agar guru mampu melihat minat, dan kemampuan siswa dalam pembelajaran. (Dodi, 2016).

Nezhad \& Vahedi (2011) mengungkapkan bahwa pendidikan dan psikologi sangat berhubungan erat, psikologi pendidikan memberikan makna bahwa bukan hanya siswa kelas atas yang memiliki hak untuk belajar, namun setiap individu memilikinya, setiap sekolah wajib memahami psikologi pendidikan dan menjadikan suatu rancangan guru sebelum mengajar. Konflik intrapersonal akan terjadi ketika individu harus memilih diantara beberapa pilihan kemudian merasa bimbang mana yang harus dipilih untuk dilakukan, namun juga tetap harus menerima konsekuensi dari pilihannya tersebut. Dalam hal ini adalah, konflik intrapersonal dalam pembelajaran matematika pada siswa. Pada masa ini akan terjadi berbagai macam kebingungan, pertimbangan, keraguan hingga konflik diri yang bisa terjadi dan berpengaruh kepada bagaimana ia menjalani hidupnya ke depan nanti (Akhrani \& Supriyono, n.d.; Y, Natascha Dessya, 2013).
Kondisi emosional dan psikologis yang tidak stabil menyebabkan konflik intrapersonal atau konflik dengan dirinya sendiri pada saat belajar matematika, berdasarkan penelitian Henra (2020) sebelumnya menemukan bahwa pada pembelajaran matematika ditemukan siswa yang mengalami konflik approach-approach, avoidanceavoidance, dan approach avoidance, dimana penyebab konflik intrapersonal tersebut karena kecemasan dan ketakutan siswa dalam belajar matematika.

Konflik intrapersonal siswa dalam belajar matematika sebelumnya telah dilakukan namun pada kondisi pembelajaran langsung atau tatap muka saja, penelitian ini akan menganalisis ulang konflik intrapersonal siswa dalam belajar matematika pada kondisi pembelajaran secara daring synchronous (Henra, 2020).

Seperti yang diketahui bahwa pembelajaran daring memiliki beberapa kendala dalam pelaksanaannya khususnya di Indonesia yang secara mendadak dan terpaksa menyesuaikan dengan kondisi yang ada sehingga memberikan dampak pada kondisi mental dan pemahaman materi pada siswa dalam belajar matematika. Berdasarkan hasil penelitian sebelumnya juga dikatakan konflik intrapersonal ini jika dibiarkan berulang secara terus menerus akan berdampak pada kesehatan jiwa peserta didik. Sehingga perlu diteliti lebih dalam lagi khususnya pada situasi pandemic covid-19 yang mengharuskan proses pembelajaran dilakukan secara daring.

Untuk menggali lebih dalam lagi konflik intrapersonal yang terjadi pada siswa pada saat belajar matematika diperlukan pendekatan secara emosional terhadap siswa yang mengalaminya, penguatan pada instrumen kuesioner, observasi dan wawancara sangat 
DOI: https://doi.org/10.24127/ajpm.v10i3.3801

diperlukan dengan menggunakan pendekatan personal agar siswa dapat lebih lepas dan nyaman dalam memberikan informasi tentang perasaan mereka saat belajar matematika secara daring synchronous.

Penelitian ini akan memberikan gambaran tentang konflik intrapersonal yang dialami siswa saat belajar matematika secara daring synchronous di masa pandemic Covid-19. Penelitian ini diharapkan menjadi referensi guru dalam melakukan proses pembelajaran matematika secara daring dan memberikan petunjuk kondisi emosional dan psikologis siswa ketika belajar matematika secara daring synchronous.

\section{METODE PENELITIAN}

Penelitian ini menggunakan metode deskriptif dengan pendekatan kualitatif. Penelitian ini dilaksanakan di SMA Negeri 3 Wajo pada siswa kelas XI yang melakukan pembelajaran matematika secara daring menggunakan Zoom. Penelitian ini merupakan penelitian eksplorasi kasus, dengan menerapkan kasus tertentu dalam menganalisis konflik yang akan terjadi pada peserta didik dengan menggunakan instrumen penelitian berupa kuesioner, lembar observasi, dan pedoman wawancara.

Jumlah partisipan sebanyak 44 siswa namun siswa yang diamati adalah siswa yang telah dipilih menjadi subjek fokus penelitian berdasarkan hasil kuesioner dimana masing-masing kasus diambil 2 orang subjek untuk masingmasing kasus. Untuk kasus Approachapproach dikodekan SAPP01 dan SAPP02, Avoidance-avoidance dikodekan SAVV01 dan SAVV02, dan untuk Approach-avoidance dikodekan SAPV01 dan SAPV02 dengan total subjek keseluruhan sebanyak 6 siswa.
Penelitian ini dibagi menjadi 3 tahap. Pada tahap pertama penyebaran kuesioner online untuk screening karakter pada siswa untuk melihat siswa yang berpotensi mengalami konflik intrapersonal serta pendapat mereka dalam pembelajaran daring. Indikator karakter dibagi menjadi 2. Didalam penelitian Henra (2020) ia mengutip hasil penelitian Friedman dan Roseman tentang kepribadian manusia yang mereka klasifikasikan dengan profil tipe A dan tipe B, dimana karakter A, yaitu: 1) tidak bisa diam, 2) berjalan cepat, 3 ) makan cepat, 4) bicara cepat, 5) tidak sabaran, 6) melakukan dua hal sekaligus, 7) tidak suka waktu senggang, 8) terobsesi dengan angka-angka, 9) mengukur kesuksesan dengan kuantitas, 10) agresif, 11) kompetitif, 12) selalu merasa dikejar waktu.

Sedangkan untuk karakter B, yaitu 1) tidak peduli dengan waktu, 2) sabar, 3) tidak suka membual, 4) bermain untuk kesenangan bukan kemenangan, 5) santai, 6) tidak dikejar waktu, 7) bertingkah laku tenang, 8) tidak terburuburu. Menurut Friedman dan Roseman orang yang memiliki karakter A cenderung mengalami konflik intrapersonal.

Lalu pada tahap kedua dilakukan penerapan kasus pada proses pembelajaran menggunakan Zoom dan diobservasi untuk melihat kondisi peserta didik. Kasus yang didesain untuk jenis konflik Approach-approach adalah Guru memberikan 2 butir soal kepada siswa tentang materi yang diajarkan pada saat itu dengan tingkat kerumitan soal sedang, kemudian guru memberikan kesempatan siapa yang bisa menjawab salah satu soal tersebut atau keduanya.

Untuk kasus jenis konflik Avoidance-avoidance adalah Guru memberikan 1 butir soal tentang materi 
yang diajarkan pada saat itu dengan tingkat kerumitan soal sedang, kemudian guru menyampaikan jika jawabannya salah akan mendapatkan pengurangan poin nilai.

Kemudian untuk kasus jenis konflik Approach-avoidance adalah Guru memberikan 1 butir soal tentang materi yang diajarkan pada saat itu dengan tingkat kerumitan soal sedang, kemudian guru menyampaikan jika jawabannya benar akan mendapatkan penambahan poin nilai.

Pada tahap ketiga dilakukan wawancara kepada peserta didik yang menjadi subjek utama konflik untuk mendalami hal yang mereka rasakan dan alami ketika berada pada kasus yang dialami pada proses pembelajaran.

Proses analisis data yang digunakan adalah model Miles \& Huberman, yakni pengumpulan data, reduksi data, penyajian data, dan verifikasi yang dilakukan secara siklis (Miles, Huberman, \& Saldaña, 2018).
Triangulasi teknik digunakan dalam penelitian ini dengan mengecek data dari cara yang berbeda namun pada sumber yang sama gunak melihat keabsahan data.

Analisis dilakukan sejak pertama pada saat pengisian kuesioner online, setelah semua data terkumpul kemudian dilakukan reduksi terhadap data hasil wawancara dengan menghubungkan hasil kuesioner dan observasi, selanjutnya dilakukan penarikan kesimpulan.

\section{HASIL DAN PEMBAHASAN}

Konflik intrapersonal bisa dikatakan selalu ada dalam proses pembelajaran khususnya matematika, namun kondisi tersebut sangat tidak kasat mata, diperlukan pendekatan khusus dalam menangani hal tersebut. Hasil screening karakter siswa menggunakan kuesioner online terlihat pada Gambar 1.

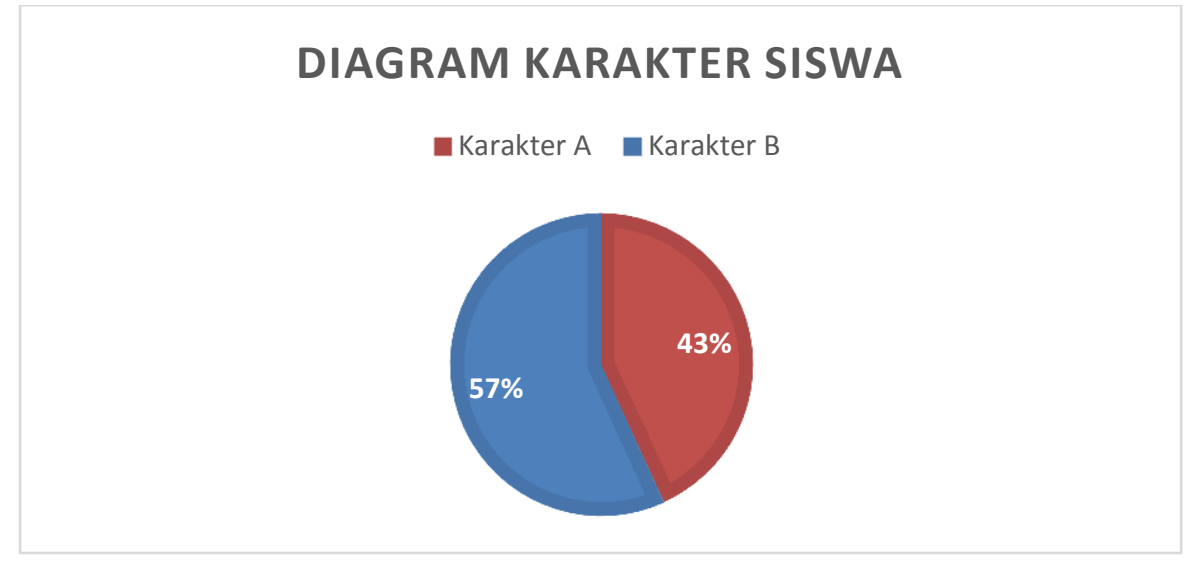

Gambar 1. Diagram karakter siswa

Pada Gambar 1, terlihat bahwa sebanyak $43 \%$ siswa memiliki karakter A dan $57 \%$ siswa memiliki karakter B, dimana karakter A cenderung mengalami konflik intrapersonal. Sehingga fokus subjek pada tahap selanjutnya adalah semua siswa yang memiliki karakter A. Dari $43 \%$ siswa berkarakter A akan menjalani tahap fokus observasi pada saat proses pembelajaran dengan intervensi kasus yang sudah disiapkan sebelumnya.

Untuk gambaran kendala yang dihadapi siswa dalam belajar daring secara synchronous dapat dilihat pada Gambar 2. 
DOI: https://doi.org/10.24127/ajpm.v10i3.3801

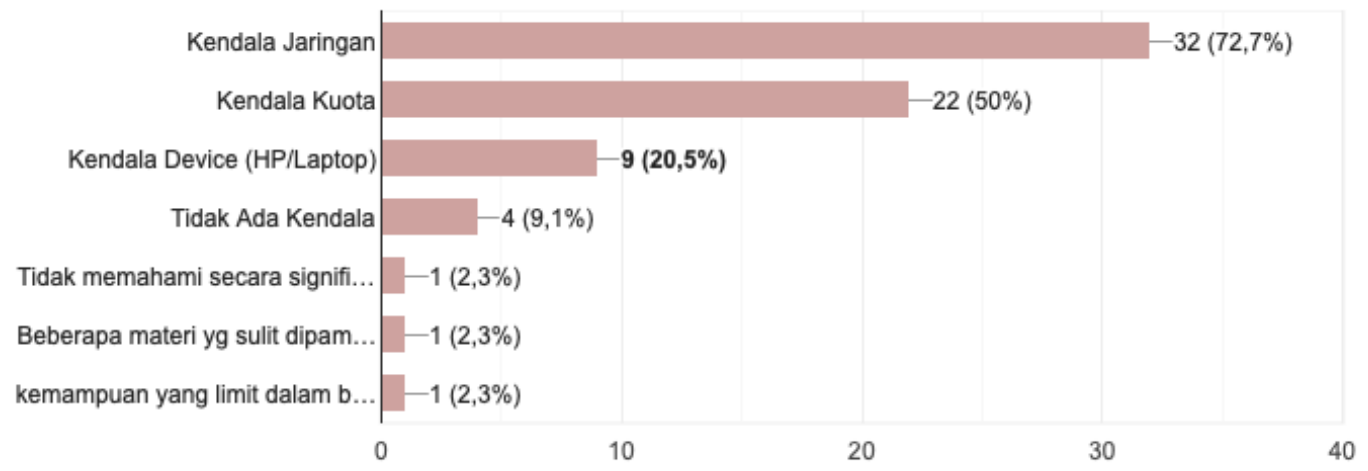

Gambar 2. Diagram kendala belajar daring siswa

Berdasarkan Gambar 2. Terkait data tentang kendala siswa dalam pembelajaran daring, terlihat bahwa sebesar $72,2 \%$ yang menjadi faktor utama penghambat siswa belajar adalah jaringan. Hal ini sejalan juga dengan penelitian Annur (2020) yang menyatakan bahwa peserta didik mengalami kendala dalam pembelajaran selama masa pandemic Covid-19 salah satunya adalah kendala teknis yang mengganggu jalannya komunikasi.

Gangguan komunikasi karena jaringan yang tidak baik dapat menjadi faktor penyebab konflik, kesulitan semantik, kesalahpahaman, dan kebisingan saluran komunikasi merupakan faktor penghambat dalam komunikasi (Muslim, 2014)

Hasil pada kasus I untuk konflik Approach-approach yang dialami subject SAPP01, subjek memilih untuk mengajukan diri menyelesaikan kedua soal yang diberikan, berdasarkan hasil wawancara SAPP01 beralasan ingin mendapatkan nilai lebih dan menguasai lebih banyak materi, kondisi fisik dan emosional SAPP01 agresif dan bimbang, sedangkan pada subjek SAPP02 mengerjakan satu soal kemudian kembali mengajukan diri mengerjakan soal berikutnya, berdasarkan hasil wawancara SAPP02 beralasan ingin menjawab rasa penasaran terhadap soal tersebut, kondisi fisik dan emosional SAPP02 terlihat ragu-ragu dan bimbang. Namun keduanya merasa puas atas pencapaian mampu menjawab 2 soal yang diberikan.

Pada kasus konflik Approachapproach SAPP01 dan SAPP02 mengalami kondisi dimana menghadapi valensi positif yang bersamaan terjadi dan saling tarik menarik ketika mereka harus memilih salah satu soal diantara dua soal yang sama mudahnya untuk mereka jawab, dan penyelesaian konflik ini mereka dapat atasi dengan menyelesaikan kedua soal tersebut. Konflik ini dinyatakan selesai jika kepuasan diri individu atau subjek terpenuhi.

Hasil pada kasus II untuk konflik Avoidance-avoidance yang dialami subjek SAVV01 memilih untuk menjawab soal meskipun hasilnya salah, berdasarkan hasil wawancara SAVV01 merasa tidak mampu menjawab soal tetapi karena takut dan malu dengan terpaksa menjawab soal seadanya, pemahamannya terhadap materi sangat kurang ketika belajar secara daring synchronous, kondisi fisik dan emosional siswa terlihat cemas, takut, dan malu, sedangkan SAVV02, memilih untuk tidak menjawab dan mencari alasan agar lain agar tidak ditanya oleh guru, berdasarkan hasil wawancara SAVV02 beralasan karena 
tidak tahu jawaban dan tidak paham maksud soal, terlebih kondisi jaringan di daerahnya sangat buruk sehingga mengganggu proses belajar daring secara synchronous, kondisi fisik dan emosional subjek terlihat takut dan malu. SAVV01 dan SAVV02 merasa terbebani dan merasa sangat malu atas kejadian tersebut karena selain malu juga mendapat pengurangan poin nilai.

Pada kasus konflik Avoidanceavoidance SAVV01 dan SAVV02 mengalami kondisi dimana menghadapi valensi negatif yang bersamaan terjadi dan saling tarik menarik ketika mereka harus menjawab soal yang mereka tidak tahu jawabannya dan ketika tidak menjawab akan merasa malu serta mendapatkan pengurangan poin, kondisi ini dapat berlangsung lama jika subjek berada di tengah-tengah valensi tersebut. Subjek SAVV01 memilih menyelesaikan konflik ini dengan menjawab soal dengan terpaksa dan jawaban yang seadanya, dengan menanggung konsekuensi malu dan mendapat pengurangan poin nilai, sedangkan SAVV02 tidak mampu menyelesaikan konflik yang dialaminya dan memilih untuk mengambil posisi flight from reality atau lari dari kenyataan yang harus di hadapi. Konflik ini dinyatakan selesai jika subjek mampu penghadapai salah satu valensi negatif, tetapi jika subjek terperangkap di antara kedua valensi negatif tersebut dan tidak mampu menghadapi salah satu atau keduanya, hal ini dapat menimbulkan rasa kebencian yang besar jika dibiarkan terlalu lama.

Hasil pada kasus III konflik Approach-avoidance yang dialami subjek SAPV01 memilih untuk diam ketika mendapat soal dari guru, berdasarkan hasil wawancara SAPV01 beralasan malu untuk menjawab karena tidak terbiasa menjawab soal di dalam forum atau kelas entah itu langsung maupun online, walaupun sebenarnya SAPV01 tahu jawaban soal tersebut, kondisi fisik dan emosional SAPV01 takut, malu, dan merasa bimbang, sedangkan SAPV02 juga memilih untuk diam saja dan tidak menjawab, berdasarkan hasil wawancara SAPV02 beralasan malu dan tidak ingin dikatakan sebagai siswa sok pintar walaupun SAPV02 juga tahu jawaban dari soal tersebut, kondisi fisik dan emosional SPAV02 terlihat tidak yakin, ragu-ragu, dan malu. SAPV01 dan SAPV02 merasa sangat menyesal ketika mengetahui jika jawaban yang mereka pikirkan sebenarnya benar tetapi sudah dijawab oleh temannya yang lain, sehingga muncul penyesalan yang mendalam dan menyalahkan diri sendiri karena tidak berani menjawab dan gagal mendapatkan poin tambahan dari guru.

Pada kasus konflik Approachavoidance SAPV01 dan SAPV02 mengalami kondisi dimana menghadapi valensi positif negatif yang bersamaan terjadi dan saling tarik menarik ketika mereka ingin menjawab soal yang mereka tahu jawabannya namun karena merasa malu dan adanya beban lain sehingga muncul valensi negatif tersebut, kondisi ini dapat berlangsung lama jika subjek berada di tengahtengah valensi tersebut dan dapat menimbulkan frustasi berat jika subjek tidak mampu melakukan control emosional yang tepat. Meskipun tujuan valensi positif sudah dicapai valensi negatif tetap akan melekat dan menimbulkan frustasi. SAPV01 dan SAPV02 memilih menghindari valensi tersebut, tetapi muncul valensi lain yang lebih mempengaruhi kondisi emosional mereka yakni penyesalan dan rasa bersalah. Konflik ini tidak dapat dijamin sepenuhnya dapat selesai karena valensi positif dan negatif pada konflik ini 
DOI: https://doi.org/10.24127/ajpm.v10i3.3801

saling terikat sehingga diupayakan untuk menghindari konflik jenis ini dalam pembelajaran.

Hasil penelitian ini sejalan dengan apa yang telah diteliti sebelumnya oleh Henra (2020) yang menyatakan bahwa konflik Approach-approach dialami oleh siswa yang berkarakter jenis karakter A menunjukkan kondisi bimbang, ragu-ragu, dan agresif, konflik Avoidance-avoidance menunjukkan kondisi takut, cemas, dan malu, dan konflik Approach-avoidance menunjukkan kondisi ragu-ragu, cemas, dan malu.

Kasus konflik intrapersonal juga pernah diteliti sebelumnya oleh Paramitha (2018) yang menunjukkan bahwa faktor penyebab mahasiswa EA mengalami konflik intrapersonal meliputi faktor internal yang terdiri dari kematangan emosi yang rendah, kegagalan saat memilih pilihan membuat sulit untuk memilih pilihan. dihadapi lebih jauh lagi, tidak memahami kelebihan dan kekurangan dirinya.

Pengetahuan akan konflik, jenis konflik, penyebab, dan dampak konflik membantu pemimpin pendidikan untuk menentukan strategi manajemen konflik. Untuk sampai pada penentuan strategi manajemen konflik secara tepat dan benar perlu diketahui tujuan pengelolaan, faktor yang mempengaruhi pengelolaan, pengetahuan mengenai proses konflik, cara mengelola konflik, dan kemampuan melihat tanda-tanda pengelolaan konflik yang benar (Muslim, 2014).

Subjek yang mengalami konflik intrapersonal tersebut akan berusaha semampunya melakukan pertahanan diri untuk melawan simpotm yang dapat berkembang menjadi syndrome dan menganggu mental individu (Perdiansyah, 2015), pertahanan diri yang dilakukan seperti pada beberapa subjek yang berusaha menghadapi valensi negatif tersebut.

Faktor yang mempengaruhi emosional siswa belajar secara daring adalah jaringan, seperti hasil pada gambar 2, mayoritas siswa mengeluhkan terganggu karena kendala jaringan internet, hal kecil seperti ini tentunya sangat berpengaruh pada kondisi mental siswa yang tertekan karena materi dan teknis jaringan mereka.

Namun berdasarkan data kuesioner kebanyakan siswa senang belajar matematika secara daring synchronous karena dianggap lebih interaktif dan bisa bertatap muka langsung secara maya, data tersebut tergambar pada Gambar 3.

Apakah Anda Suka Belajar Matematika secara Daring Synchronous (teleconference)? 44 jawaban

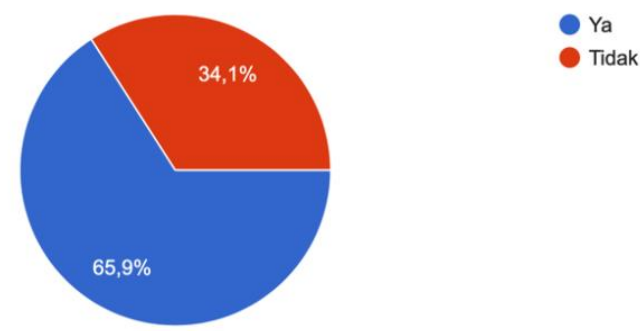

Gambar 3. Diagram tentang kesenangan siswa belajar daring secara syncrhonous

Berdasarkan Gambar 3, terlihat lebih banyak siswa menyatakan senang belajar matematika secara daring synchronous menggunakan Zoom daripada menyatakan tidak senang. Hal ini sejalan dengan hasil penelitian 
DOI: https://doi.org/10.24127/ajpm.v10i3.3801

Hamidy (2021) menyatakan bahwa peserta didik lebih senang belajar menggunakan Zoom dan berdampak baik pada hasil belajar mereka.

Tetapi hal ini bukan menjadi dasar utama untuk menyatakan bahwa pembelajaran dari synchronous dapat mengurangi konflik intrapersonal yang terjadi pada siswa, karena telah terbukti bahwa dalam pembelajaran langsung dan daring synchronous siswa tetap mengalami konflik intrapersonal. Karena konflik intrapersonal tidak dapat diatasi hanya dengan membuat siswa senang dalam model pembelajaran, tetapi diperlukan pendekatan emosional yang lebih dalam lagi agar mereka bisa terlepas dari valensi-valensi yang ada dalam pikiran mereka. Kondisi ini dapat dilihat pada hasil kuesioner pada Gambar 4.

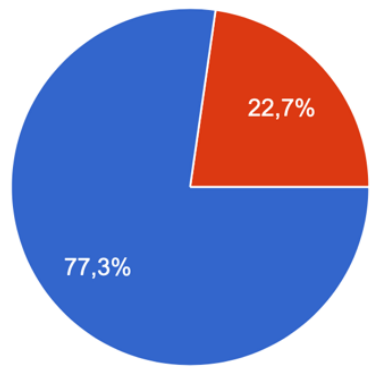

Gambar 4. Diagram Perasaan Takut Siswa Ketika Mengerjakan Soal Matematika

Berdasarkan Gambar 4, terlihat lebih banyak siswa merasa takut ketika disuruh mengerjakan soal atau menjawab pertanyaan matematika yang diajukan guru secara langsung maupun secara online menggunakan Zoom, daripada merasa tidak takut.

Berdasarkan beberapa penelitian tentang kecemasan matematika, terlihat bahwa kecemasan matematika sangat berpengaruh negatif terhadap hasil belajar/prestasi belajar maupun berpengaruh terhadap kemampuan matematis peserta didik. Seorang guru atau pengajar harus mengerti tentang bagaimana indikator kecemasan matematika siswa, sehingga dapat mengatasi kecemasan matematika yang terjadi pada siswa (Syafri, 2017)

Hal ini juga tergambar pada hasil penelitian Wulan (2021) yang menyatakan bahwa psikologi siswa SMP dalam pembelajaran matematika melalui pembelajaran online selama pandemi Covid-19 termasuk dalam kategori sedang, hal ini karena dipengaruhi oleh faktor yaitu emosi, keyakinan dan skema diri, minat, dan motivasi siswa.

Implikasi dari penelitian ini adalah tingkat kesenangan siswa dalam model atau media pembelajaran yang digunakan tidak menjamin kenyamanan emosional dan psikologi siswa tersebut. Masih terjadi konflik intrapersonal pada beberapa siswa yang tidak kasat mata oleh guru, sehingga hasil penelitian ini dapat menjadi petunjuk bagi guru untuk lebih mendekatkan diri dan membantu siswa secara emosional dalam menyelesaikan permasalahan mereka terhadap materi matematika. Siswa 
DOI: https://doi.org/10.24127/ajpm.v10i3.3801

yang tidak menjawab ketika ditanya bukan berarti bodoh atau tidak tahu jawabannya, tetapi karena adanya faktor tekanan valensi yang terjadi pada diri mereka sehingga peranan guru secara langsung sangat dibutuhkan dalam meningkatkan kualitas mental siswa dalam belajar matematika.

\section{KESIMPULAN DAN SARAN}

Kesimpulan yang diperoleh pada penelitian ini adalah Konflik intrapersonal tetap dialami oleh siswa yang sedang belajar matematika secara daring synchronous menggunakan Zoom. Siswa yang mengalami konflik intrapersonal mengalami kondisi fisik dan mental seperti takut, cemas, bingung, ragu-ragu, dan terlihat tegang ketika belajar. Hal ini tidak terlepas juga karena faktor pemahaman mereka bahwa belajar matematika itu susah dan menakutkan karena masih banyak siswa mengatakan takut ketika akan menjawab soal, terlebih adanya gangguan teknis jaringan pada saat belajar daring yang membuat emosi sedikit terganggu.

Berdasarkan hasil penelitian ini juga disampaikan saran pengembangan berikutnya untuk penelitian serupa agar: (1) hendaknya memastikan siswa berada dalam kondisi sehat dan tidak ada masalah pribadi dari rumah, (2) hendaknya memastikan model pembelajaran yang digunakan sudah menerapkan pendekatan emosional, dan (3) memastikan guru tidak ada konflik kepentingan dengan siswa dan atau individu tertentu, sebab hal seperti ini sangat berpengaruh dalam proses pembelajaran secara umum, dan khususnya dalam pembelajaran matematika.

\section{DAFTAR PUSTAKA}

Akhrani, L. A., \& Supriyono, Y. (n.d.). KONFLIK INTRAPERSONAL DALAM MEMELUK AGAMA
PADA REMAJA DENGAN ORANG TUA YANG BERBEDA AGAMA. Retrieved from shorturl.at/ruMR2

Al Halik, \& Aini, Z. (2020). Analisis Keaktifan Siswa dalam Proses Pembelajaran Daring di Masa Pandemi COVID-19. ENLIGHTEN (Jurnal Bimbingan Dan Konseling Islam), 3(2), 131-141. https://doi.org/10.32505/enlighten.v 3i2. 1887

Annur, M. F. (2020). Analisis Kesulitan Mahasiswa Pendidikan Matematika Dalam Pembelajaran Daring Pada Masa Pandemi Covid-19. Jurnal Kajian, Pnelitian Dan Pengembangan Kependidikan, 11, 195-201. https://doi.org/https://doi.org/10.31 764/paedagoria.v11i2.2544

Dodi, N. (2016). Pentingnya guru untuk mempelajari psikologi pendidikan. NUSANTARA: Jurnal Ilmu Pengetahuan Sosial, 1(1). Retrieved from http://jurnal.umtapsel.ac.id/index.php/nusantara/arti cle/view/93/93

Fahmi, M. H. (2020). KOMUNIKASI SYNCHRONOUS DAN ASYNCHRONOUS DALAM ELEARNING PADA MASA PANDEMIC COVID-19. Jurnal Nomosleca, 6(2). https://doi.org/10.26905/nomosleca. v6i2.4947

Hamidy, A. (2021). Zoom Meeting vs Google Classroom: Perbedaan Hasil Belajar Matematika Berdasarkan Platform Pembelajaran Daring. Tarbiyah Wa Ta'lim: Jurnal Penelitian Pendidikan Dan Pembelajaran, 8(1), 61-68. https://doi.org/https://doi.org/10.21 093/twt.v8i1.3225

Henra, K. (2020). Analisis Konflik Intrapersonal pada Pembelajaran Matematika dan Dampak yang ditimbulkan Pada Siswa Kelas XII SMK Persada Wajo. Celebes Education Review, 2(1), 43-49. 
DOI: https://doi.org/10.24127/ajpm.v10i3.3801

https://doi.org/10.37541/cer.v2i1.34 5

Miles, M. B., Huberman, A. M., \& Saldaña, J. (2018). Qualitative data analysis: A methods sourcebook. Retrieved from https://books.google.co.id/books?hl $=\mathrm{id} \& \mathrm{lr}=\& \mathrm{id}=1 \mathrm{Ch} \_D w A A Q B A J \& o i$ $=$ fnd $\& p g=P P 1 \& d q=Q$ ualitative + dat a+analysis: $+\mathrm{A}+$ methods+sourceboo k. $+\& o t s=2$ SbqMCvjdh $\&$ sig $=o Q A$ MzuB3eus9iLIpvmyWorhCIWc\&r edir_esc $=\mathrm{y} \# \mathrm{v}=$ onepage $\& \mathrm{q}=$ Qualitat ive data analysis\%3A A methods sourcebook. \&f=false

Muslim, A. (2014). Manajemen Konflik Interpersonal Di Sekolah. Administrasi Pendidikan, FIP, IKIP Mataram, 1(1), 17-25. Retrieved from https://ejournal.undikma.ac.id/index.php/pe dagogy/article/view/3055

Narayana, I. W. G. (2016). Analisis terhadap hasil penggunaan metode pembelajaran synchronous dan asynchronous. Semnasteknomedia Online, 4(1), 139-144. Retrieved from

https://ojs.amikom.ac.id/index.php/ semnasteknomedia/article/view/125 5

Nezhad, A. S., \& Vahedi, M. (2011). The Role of Educational Psychology in Teacher Education Programs. Procedia - Social and Behavioral Sciences, 30, 327-330. https://doi.org/10.1016/j.sbspro.201 1.10 .064

PARAMITHA, K., Sofah, R., \& Sumarni, S. (2018). STUDI KASUS SISWA "EA" YANG MENGALAMI KONFLIK INTRAPERSONAL DI SEKOLAH MENENGAH ATAS NEGERI 10 PALEMBANG. Retrieved from Sriwijaya University website: http://repository.unsri.ac.id/id/eprin $\mathrm{t} / 7714$
Perdiansyah, V. A. M. (2015). Komflik Intrapersonal Anggota Keluarga (Studi Kasus Keluarga yang memiliki Anak Ataupun Saudara Kandung dengan Kecenderungan Gangguan Identitas Gender). 151, 10-17. https://doi.org/10.1145/3132847.31 32886

Siregar, N. (2018). Psikologi dan Pembelajaran Matematika.

Syafri, F. S. (2017). Ada Apa dengan Kecemasan Matematika? Journal of Medives, 1(1), 59-65. Retrieved from http://ejournal.ivet.ac.id/index.php/matema tika/article/view/458/516

Wiryanto, W. (2020). PROSES PEMBELAJARAN MATEMATIKA DI SEKOLAH DASAR DI TENGAH PANDEMI COVID-19. Jurnal Review Pendidikan Dasar: Jurnal Kajian Pendidikan Dan Hasil Penelitian, 6(2), 125-132. https://doi.org/http://dx.doi.org/10.2 6740/jrpd.v6n2.p125-132

Wulan, D. R., Rosita, C. D., \& Nopriana, T. (2021). Bagaimana Psikologi Siswa SMP dalam Pembelajaran Matematika Online pada Masa Pandemi Covid-19. ... Nasional Pendidikan Matematika ..., 5(1), 51-65. Retrieved from http://jurnal.ugj.ac.id/index.php/JN PM/article/view/4392

Yamagata-Lynch, L. C. (2014). Blending online asynchronous and synchronous learning. International Review of Research in Open and Distributed Learning, 15(2). https://doi.org/https://doi.org/10.19 173/irrodl.v15i2.1778 